\title{
Froskens død
}

\author{
Digitalis kan være vanskelig å dosere, noe problemene i forbindelse med overgangen fra digitoksin til digoksin \\ har illustrert. Tidligere var det å fremstille preparater med konstant styrke komplisert. «Dette kan vel for en \\ stor del forklare de kliniske variasjoner som forekommer ved digitalisterapien,» skriver cand.pharm. Dahl \\ i Tidsskriftet nr. 20/1931. Løsningen: Et internasjonalt «standard-digitalispulver» med konstant styrke angitt \\ i «F.D.» - froskedose - «den minste dose pr. gr. frosk som skal til for å drepe dyret» (Tidsskr Nor Lægeforen \\ $1931 ; 51: 841-3)$
}

\section{En farmakologisk undersøkelse av de almindeligste spesialpreparater av digitalis.}

Av cand. pharm. amanuensis G. Dahl, Oslo.

Ved Farmakologisk institutt er der i den senere tid foretatt endel undersøkelser over digitalisspesialiteter under ledelse av professor $\mathrm{K} l$ a u s Hanse n; disse undersøkelser viser, at der fremdeles er temmelig stor variasjon i de forskjellige spesialiteters innhold av glykosider, samt at et og samme preparat heller ikke viser konstant styrke fra år til annet. Ved standardiseringen er benyttet «froskemetoden», som er anbefalt av Nasjonenes forbunds hygienekomité i Genf 1925 og optatt i Kommentar til den tyske farmakopø. Fremgangsmåten er i korthet følgende: Man benytter kun hanfrosk, rana temporia av 30-40 gr. vekt. Dyrene opbevares i større kasser med rindende ledningsvann av temperatur ikke over $17^{\circ}$. Nogen timer før forsøket blir froskene anbragt i laboratoriet under hver sin nummerte glassklokke på en fuktig glasstallerken. Like før injeksjonen blir frosken tatt ut og tørret varsomt $\mathrm{i}$ et håndklæ. Man utpresser urinen og veier dyret med en nøiaktighet av 0,5 gr. Digitalisopløsningen blir derefter injisert i buklymfesekken med en sprøite indelt $1 / 100 \mathrm{~cm} .^{3}$. Mere enn $0,5 \mathrm{~cm} \cdot{ }^{3}$ bør ikke injiseres på en gang. Ved svakt virkende preparater må man derfor også injisere opløsning $\mathrm{i}$ lårlymfesekken. Man injiserer digitalisopløsning i regelmessig stigende doser pr. gr. frosk opover i en større serie av dyr, og resultatet avleses efter 24 timer.

Dosis minima letalis er den minste dose pr. gr. frosk som skal til for å drepe dyret. Denne dose kalles en froskedose = F.D. Forutsatt at preparatet er virksomt, vil dyrene leve op til et visst punkt i serien; men herfra videre opover vil de dø. Middeltallet mellem den minst virksomme og den størst uvirksomme dose gir den første tilnærmede verdi for preparatets styrke. Hvor det gjelder å bestemme verdien med maksimal nøiaktighet, blir der derefter foretatt undersøkelser med flere serier dyr, som injiseres i doser omkring denne middelverdi.

Standardiseringen er avsluttet når av to doser, som ligger 10 pct. fra hverandre, den minste dose dreper $\mathrm{mindre}$ e $\mathrm{n} n$ halvparten av en serie på 10 frosk, som injiseres med samme dose pr. gr. frosk, og den største dreper m e $\mathrm{r}$ e $\mathrm{n} n$ halvparten av en lignende serie.

Det internasjonale digitalis-standardpreparat inneholder ca. 2000 F.D. pr. gr. Med en variasjonsbredde på \pm 15 pct. betinger dette et minimumsinnhold pr. gr. blade av 1700 F.D., hvilket er lagt til grunn for beregningen hvor preparatets styrke er angitt å svare til en viss mengde folium digitalis pr. $\mathrm{cm} .{ }^{3}$ eller pr. tablett.

I nedstående tabell har jeg sammenstillet: A. Den i deklarasjonen angitte styrke. B. Den funne verdi. C. De av Apotekernes kontrollaboratorium i Stockholm i 1926 funne verdier hvor disse foreligger.

Som man ser varierer de funne verdier for tablettenes vedkommende fra 150 pct. av den angitte verdi (Mrk. A.) ned til 30 pct. av den angitte verdi (Mrk. C.), og for de flytende preparaters vedkommende fra 115 pct. av den angitte verdi (Mrk. D.) ned til 10 pct. (Mrk. J.).

Dette kan vel for en stor del forklare de kliniske variasjoner som forekommer ved digitalisterapien. Disse uregelmessigheter må for en vesentlig del tilskrives at man ennu ikke er nådd helt frem til den riktige måte å bevare digitalisglykosidene på.

Den inntil den senere tid herskende forvirring ved preparatenes styrkeangivelse burde nu, efterat man har fått et internasjonalt standard-digitalispulver med konstant styrke uttrykt i F.D., komme til ophør ved at preparatene angis å motsvare så og så meget av det internasjonale standardpulver.

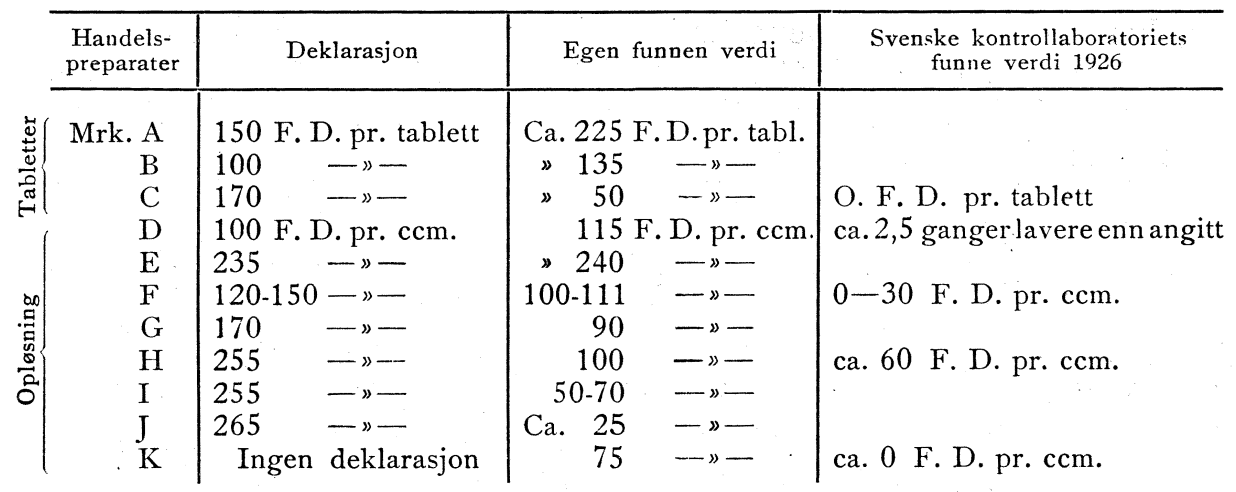

